\title{
Reconstruction of Transport Regulatory On Marine Toll to Support Sea Connectivity Based On Pancasila Justice
}

\begin{abstract}
Hartanto ${ }^{1}$
Abstract

The idea of marine toll is an attempt to realize the first Nawacita that is strengthening Indonesian identity as a maritime country and the third of Nawacita, that is to develop Indonesia from the periphery to strengthen these areas and villages within the framework of a unitary state, in addition to the marine toll is also a confirmation that the country is actually present to all areas through ships that visited the region. Accelerating infrastructure development in particular the implementation of toll expressway connectivity of sea or ocean (sea connectivity) if it can be done well it will be able to unite the archipelago by sea, especially to unite Indonesian islands in one national connectivity. Based on the documents of the National Medium Term Development Plan (RPJMN) 20152019 , in the framework of the development of national connectivity to achieve a balance of development, the government has set a target increase of 24 strategic ports to support marine toll program ${ }^{2}$. The marine toll presence is expected to drive the wheels of the economy efficiently and equitably so that Pancasila justice can be realized.

Keywords: Reconstruction; Marine Toll; Connectivity; Pancasila Justice.
\end{abstract}

\section{Introduction}

The idea of marine toll is not a mere discourse to overcome the problems of price disparities occur in Indonesia, marine toll has been successfully carried out by Japan and the Philippines, the islands both countries managed to reduce the cost of logistics so that it becomes cheaper and managed to push the price disparity with sea connectivity ${ }^{3}$.

Understanding marine toll emphasized by President Joko Widodo is a concept of strengthening the cruise line focused on the eastern part of Indonesia. The concept is in addition to connecting cruise lines from west to east Indonesia will also facilitate trade access of Pacific countries to the southern part of the East Asian countries. The idea of the Marine toll concept will open a regional access by making a large-scale two-port hub that can serve international ships of big trade above 3,000 TEUs ${ }^{4}$ or class Panamax vessels of 6000 TEUs. Through the realization of the plan is expected to Indonesia may have a significant role in supporting the

\footnotetext{
${ }^{1}$ Director of Poltektrans SDP Palembang and Student Doctor of Law, Sultan Agung Islamic University in Semarang, email: hartantosatya@gmail.com.

2Prihartono, Bambang. 2015. Pengembangan Tol Laut dalam RPJMN 2015-2019 dan Implementasi 2015. Badan Perencanaan Pembangunan Nasional Republik Indonesia

${ }^{3}$ https: philippines //finance.detik.com/ekonomi-bisnis/2591177/jepang-dan--success-apply-tollsea-ala-jokowi accessed on February 6, 2019 at. 08.30

${ }^{4}$ TEUs or TEU: twenty foot equivalent unit is the smallest unit in the size of the container. container size 20 feet could be called 1 box, 1 teus. container size 40 feet could be called two boxes, one teus.
} 
international logistics distribution 5 .

\section{Research Methods}

This type of research is a qualitative research and the approach that used is juridical-sociological normative law from the standpoint of sociology as an Interpretation Understanding. While collecting data with literature and interview ${ }^{6}$.

\section{Results And Discussion}

\subsection{Marine toll Concept}

Open access to the region through the implementation of the concept of Marine Toll can provide industrial opportunities cargo/logistics nationwide to participate in international distribution, which is currently $40 \%$ through the territory of Indonesia. To become players in their own country as well as the support of cabotage and cabotage beyond, so this time the government has set two ports located in front of the region as an international connectivity on the port of Kuala Tanjung and Bitung port? .

Support it, then also developed a fleet of ships/cruise port hub that connects both international as well as through national hub port of the eastern region to the western region of Indonesia. Cargo/logistics of a national hub port will be distributed to feeder ports using different vessels. Above sea connectivity concept then served by a fleet of regular and scheduled from west to east Indonesia later referred to as the marine toll concept ${ }^{8}$.

Marine toll transport concept is suitable for Indonesia, which is mostly covered are aquatic and have 17,500 large and small islands ${ }^{9}$. However, realizing the sea motorway concept not only build ports, but also must be accompanied by improvement of the national marine transportation system as a whole. If only build ports, without fixing the existing transportation system, the marine toll system launched by President Jokowi ${ }^{10}$ will be difficult to realize. Implementation marine toll should be supported by increased capacity and productivity of existing ports to speed up the flow of goods in and out of the harbor. The low productivity of the port in Indonesia can be seen from the length of time loading and unloading goods (dwelling time) at Tanjung Priok port which last year reached 5.2 days or

\footnotetext{
${ }^{5}$ Results Fields, the Directorate General of Sea Transportation, Interview with Marine Toll Section, Ms. Magdalena Laily, Jakarta, 4 July 2018

${ }^{6}$ Arikunto, S (2002). Prosedur Penelitian, Suatu Pendekatan Praktek. Jakarta: PT Rineka Cipta, p. 67 ${ }^{7}$ Dedi Darmawan. 2015."Perusahaan Pelayaran Nasional Diimbau Aktif Mengembangkan Tenaga Pelaut, Suara Karya, January 20, p. 35

8 Directorate General of Sea and INSA (Voyage Around Indonesia Employers Association) in 2005.

${ }^{9}$ Abdul Kadir Muhammad, Hukum Pengangkutan Darat, Laut, dan Udara,Bandung: 1991, p. 46

${ }^{10}$ Elfrida Gultom, Hukum Pengangkutan Laut, Jakarta: Literata Lintas Media, 2009, p. 97
} 
longer than dwelling time in the port of Malaysia and Singapore ${ }^{11}$.

\subsection{Regulations Pertaining to the Marine Toll}

Government Regulation No. 20 of 2010 on Transport in the waters (Article 65-69), and the Regulation of the Minister of Transportation No. AM 104 of 2017 on the Implementation of Transport Crossing (Article 23-25), regulates the placement of Ferryboat transport ship. Things were set up, covering ${ }^{12}$ :

1) Placement of the ship at each trail crossing must comply with the technical specifications of traffic and port facilities used to serve Transport Crossing ${ }^{13}$;

2) Placement of the number of ships on each trail crossing must consider the balance between the needs of service users and providers of transport services;

3) Placement of the vessel to be operated at the crosswalk is done by considering:

a) The need for ferry transport; and

b) The availability of port facilities used to serve the ferry transport / ferry terminals.

4) Placement of the vessel to be operated at every crosswalk must meet the requirements that have been set.

\subsection{Reconstruction of The Support Connectivity Marine Toll Transport Regulatory Based On Pancasila Justice}

There are some rules that are likely still need to be reconstructed as Law No. 17 of 2008 on the voyage as follows:

\begin{tabular}{|l|l|l|}
\hline No. & \multicolumn{1}{|c|}{ PROVISION } & \multicolumn{1}{c|}{ SANCTIONS } \\
\hline $\begin{array}{l}\text { Article 27: } \\
\text { To carry out transport activities in the } \\
\text { waters of the Indonesian citizens or } \\
\text { business entities shall have a business } \\
\text { license. }\end{array}$ & $\begin{array}{l}\text { Article 287: } \\
\text { Each person operating the vessel in transit in } \\
\text { waters without a license as referred to in } \\
\text { Article 27 shall be punished with imprisonment } \\
\text { for a period of 1 (one) year or a maximum fine } \\
\text { of Rp 200,000,000.00 (two hundred million } \\
\text { rupiah). }\end{array}$ \\
$\begin{array}{l}\text { Anticle 28 (4): } \\
\text { for river transport and lake vessels } \\
\text { operated shall have route permits } \\
\text { given by: }\end{array}$ & $\begin{array}{l}\text { Article 59: } \\
\text { administrative sanctions such as: } \\
\text { b. administrative fines; } \\
\text { c. license suspension or freezing of the }\end{array}$ \\
\hline
\end{tabular}

11 Eka Wijaya,The program "Marine Highway" The President has been run, Disparity Price Omitted,http://setkab.go.id/program-tol-laut-presiden-telah-dijalankan-disparitas- price-removed, accessed on 4 July 2019.

12 Rifdy Fachry, Imam Muchlas, Sutrisno, Department of Mathematics, Mathematics and Natural Sciences, Pattern Determination Movement Network Logistics Optimal On Sea Transportation using the minimum Spanning Tree-Based Genetic Algorithm, Journal of Science and Arts of ITS

13 http://www.transformasi.org/id/pusat-kajian/berita/umum/112-infrastruktur/520-perjelastoll-sea concept, accessed on 7 July 2019. 


\begin{tabular}{|c|c|}
\hline $\begin{array}{l}\text { a. regent / mayor is concerned for } \\
\text { ships serving the route in the } \\
\text { district / city; } \\
\text { b. governor of the province in } \\
\text { question for vessels serving the } \\
\text { route between districts / cities } \\
\text { within the province; or } \\
\text { c. Minister for ships serving the route } \\
\text { between provinces and / or } \\
\text { between countries. }\end{array}$ & $\begin{array}{l}\text { certificate; or } \\
\text { d. revocation of license or revocation of the } \\
\text { certificate. } \\
\text { Article 288: } \\
\text { Each person operating the vessel in transport } \\
\text { streams and lakes without route permits as } \\
\text { referred to in Article } 28 \text { paragraph (4) shall be } \\
\text { punished with imprisonment for a period of } 1 \\
\text { (one) year or a maximum fine of Rp } \\
200,000,000.00 \text { (two hundred million rupiah). }\end{array}$ \\
\hline $\begin{array}{l}\text { Article } 28 \text { (6): } \\
\text { In addition to having a business license } \\
\text { for ferry transport, vessels operated } \\
\text { vessel operations are required to have } \\
\text { approval given by: } \\
\text { a. regent / mayor is concerned for } \\
\text { vessels serving the port traffic in } \\
\text { the district / city; } \\
\text { b. governor of the province in } \\
\text { question for vessels serving the } \\
\text { port traffic between districts / } \\
\text { cities in the province; and } \\
\text { c. Minister for vessels serving the } \\
\text { port traffic between provinces and } \\
\text { / or inter-state }\end{array}$ & $\begin{array}{l}\text { Article 59: } \\
\text { administrative sanctions such as: } \\
\text { a. warning; } \\
\text { b. administrative fines; } \\
\text { c. license suspension or freezing of the } \\
\text { certificate; or } \\
\text { d. revocation of license or revocation of the } \\
\text { certificate. } \\
\text { Article 289: } \\
\text { Each person operating the vessel in ferry } \\
\text { transport without having the approval of the } \\
\text { operation } \\
\text { Ships referred to in Article } 28 \text { paragraph (6) } \\
\text { shall be punished with imprisonment for a } \\
\text { period of } 1 \text { (one) year or a maximum fine of Rp } \\
200,000,000.00 \text { (two hundred million rupiah). }\end{array}$ \\
\hline $\begin{array}{l}\text { Article } 38 \text { Paragraph (1): } \\
\text { Freight company in the waters shall } \\
\text { transport passengers and / or goods } \\
\text { transport especially post agreed in the } \\
\text { transport agreement. }\end{array}$ & $\begin{array}{l}\text { Article 291: } \\
\text { Everyone who does not carry out its obligations } \\
\text { to transport passengers and / or goods } \\
\text { transport especially post as referred to in } \\
\text { Article } 38 \text { paragraph (1) in criminal } \\
\text { imprisonment for a period of } 1 \text { (one) year or a } \\
\text { maximum fine of Rp 200,000,000.00 (two } \\
\text { hundred million). }\end{array}$ \\
\hline $\begin{array}{l}\text { Article 41 Paragraph (3): } \\
\text { Freight company in the waters must } \\
\text { insure liability as referred to in } \\
\text { paragraph (1) and carry out basic } \\
\text { public passenger protection insurance } \\
\text { in accordance with the provisions of } \\
\text { the legislation }\end{array}$ & $\begin{array}{l}\text { Article 292: } \\
\text { Anyone who did not insure its liability as } \\
\text { referred to in Article } 41 \text { paragraph (3) shall be } \\
\text { punished with imprisonment of six (6) months } \\
\text { and a fine of Rp 100,000,000.00 (one hundred } \\
\text { million rupiah). }\end{array}$ \\
\hline $\begin{array}{l}\text { Article } 42 \text { Paragraph (1): } \\
\text { Freight company in waters is obliged to } \\
\text { provide special facilities and services } \\
\text { for the disabled, pregnant women, } \\
\text { children under the age of five (5) years } \\
\text { old, the sick, and the elderly. }\end{array}$ & $\begin{array}{l}\text { Article 293: } \\
\text { Anyone who does not provide special facilities } \\
\text { and services referred to in Article } 42 \text { paragraph } \\
\text { (1) in criminal imprisonment of } 6 \text { (six) months } \\
\text { and a fine of Rp } 100,000,000.00 \text { (one hundred } \\
\text { million rupiah). }\end{array}$ \\
\hline $\begin{array}{l}\text { Article 46: } \\
\text { The transport of dangerous goods and }\end{array}$ & $\begin{array}{l}\text { Article 294: } \\
\text { a. Every person who transports hazardous }\end{array}$ \\
\hline
\end{tabular}




\begin{tabular}{|c|c|}
\hline $\begin{array}{l}\text { special items referred to in Article } 44 \\
\text { shall meet the following requirements: } \\
\text { a. packaging, stacking, and storage at } \\
\text { the port, handling loading and } \\
\text { unloading, and stacking and } \\
\text { storage while in the boat; } \\
\text { b. accordance with the regulations } \\
\text { and safety standards, both } \\
\text { nationally and internationally for } \\
\text { specialized vessels transporting } \\
\text { dangerous goods; and } \\
\text { certain signaling in accordance } \\
\text { with the dangerous goods being } \\
\text { transported }\end{array}$ & $\begin{array}{l}\text { goods and special items are not in } \\
\text { accordance with the requirements referred } \\
\text { to in Article } 46 \text { shall be punished with } \\
\text { imprisonment of three (3) years or a fine of } \\
\text { not more Rp400.000.000,00 (four hundred } \\
\text { million). } \\
\text { b. If the act referred to in paragraph (1) } \\
\text { resulting in loss of property shall be } \\
\text { punished with imprisonment for a period of } \\
4 \text { (four) years and a maximum fine of Rp } \\
500,000,000.00 \text { (five hundred million } \\
\text { rupiah). } \\
\text { If the act referred to in paragraph (1) } \\
\text { resulted in the death of a person and } \\
\text { property loss shall be punished with } \\
\text { imprisonment of ten (10) years and a } \\
\text { maximum fine Rp1.500.000.000,00 (one } \\
\text { billion five hundred million rupiah). }\end{array}$ \\
\hline $\begin{array}{l}\text { Article 122: } \\
\text { Each operation of ships and ports shall } \\
\text { meet the requirements of safety and } \\
\text { security and maritime environmental } \\
\text { protection. }\end{array}$ & $\begin{array}{l}\text { Article 303: } \\
\text { Each person operating the ship and the port } \\
\text { without fulfilling the requirements of safety and } \\
\text { security of shipping and the protection of the } \\
\text { maritime environment as referred to in Article } \\
122 \text { in the penal with imprisonment of } 2 \text { (two) } \\
\text { years and a fine of Rp300,000,000.00 (three } \\
\text { hundred million rupiah), }\end{array}$ \\
\hline
\end{tabular}

\section{Conclusion}

Reconstruction of the support connectivity marine toll transport regulatory had to be done to remember a few things related to operational systems and policies that are not appropriate as mandated by law and not lead to the achievement of Nawacita president Joko Widodo which basically program the toll the sea is used as a means of acceleration infrastructure development to equalize wealth and economic inequality in Indonesia. Marine toll is also used as a platform to show to the eyes of the world that Indonesia is a great nation and fit into the shaft maritime world. Therefore needed a proper legal construction in every policy and regulations related to marine toll and implement in full responsibility and the spirit of Pancasila nationalism so that justice can be realized.

\section{Bibliography}

\section{Book:}

[1] Abdul Kadir Muhammad, 1991, Hukum Pengangkutan Darat, Laut, dan Udara, Bandung. 
[2] Suhaarsimi Arikunto, 2002, Prosedur Penelitian, Suatu Pendekatan Praktek. Jakarta: PT Rineka Cipta.

[3] Dedi Darmawan, 2015."Perusahaan Pelayaran Nasional Diimbau Aktif Mengembangkan Tenaga Pelaut, Suara Karya, 20 Januari,

[4] Direktorat Jenderal Perhubungan Laut dan INSA (Asosiasi Pengusaha Pelayaran Seluruh Indonesia) Tahun 2005.

[5] Elfrida Gultom, 2009, Hukum Pengangkutan Laut, Jakarta: Literata Lintas Media.

[6] Hasil Lapangan, Direktorat Jenderal Perhubungan Laut, Wawancara dengan Bagian Tol Laut, Ibu Magdalena Laily, Jakarta, 4 Juli 2018

[7] Prihartono, Bambang. 2015. Pengembangan Tol Laut dalam RPJMN 2015-2019 dan Implementasi 2015. Badan Perencanaan Pembangunan Nasional Republik Indonesia

[8] Rifdy Fachry, Imam Muchlas, Soetrisno, Jurusan Matematika, Matematika dan Ilmu Pengetahuan Alam, Penentuan Pola Jaringan Pergerakan Logistik yang Optimal Pada Transportasi Laut menggunakan minimum Spanning Tree Berbasis Algoritma Genetika, Jurnal Sains dan Seni ITS

[9] Teus atau TEU : twenty foot equivalent unit yang merupakan satuan terkecil dalam ukuran peti kemas. peti kemas ukuran 20 feet bisa di sebut 1 box, 1 teus. peti kemas ukuran 40 feet bisa di sebut 2 box, 1 teus.

\section{Constitution:}

[1] Law No. 17 of 2008 on The Voyage.

[2] Law No. 43 of 2008 on The Territory of the State.

[3] Act No. 17 of 1985 on Ratification of the United Nations Convention On The Law of the Sea 1982 (United Nations Convention on the Law of the Sea).

[4] Presidential Decree No. 2 of 2015 on RPJMN 2015-2019.

\section{Internet:}

[1] Eka Wijaya, Program "Tol Laut" Presiden Telah Dijalankan, Disparitas Harga Dihilangkan, http://setkab.go.id/program-tol-laut-presiden-telah-dijalankandisparitas- harga-dihilangkan/ , accessed on 4 July 2019

[2] http://www.transformasi.org/id/pusat-kajian/berita/umum/112infrastruktur/520-perjelas- konsep-tol-laut,accessed on 7 July 2019 at 08.00 WIB

[3] https://finance.detik.com/ekonomi-bisnis/2591177/jepang-dan- filipinasukses-terapkan-tol-laut-ala-jokowi, accessed on 6 February 2019 at 08.30 WIB 